\title{
Comparative study of Ambient Air Quality of Jalna City (MS), India
}

\author{
B S Dobhal ${ }^{1}$, R P Shimpi ${ }^{1 *}$ \\ ${ }^{1}$ State Ambient Air Quality Monitoring Programme \\ (SAMP), Badrinarayan Barwale College, Jalna-431203, \\ (MS) India.
}

\begin{abstract}
Comparative study of ambient air quality of Jalna city was carried using air quality index (AQI). Air pollutants concentration-SO 2 , NOx, RSPM and NRSPM at residential and industrial sites for years 2016 and 2017 were compared. The monthly, seasonal and annual AQI values determined at both residential and industrial sites for these years. Results suggest better air quality at residential site for the year 2017 than 2016. While at industrial site better air quality was observed for the year 2016 than 2017. Government regulations, effective treatments in industries, appropriate waste disposal helped in minimization of pollution levels. For both the years and at both sites annual mean concentrations of $\mathrm{SO}_{2}$ and $\mathrm{NOx}$ were found within the permissible limits of Indian National Ambient Air Quality standards (NAAQS), although for both the years and at both the sites RSPM and NRSPM concentrations were observed above the norms. The annual AQI value at residential site was higher 128 for 2016 compared to 120 for 2017. While at industrial site AQI value 88 was found lower for 2016 compared to higher 126 for the year 2017.
\end{abstract}

Keywords:- Air Quality Index (AQI), Gaseous pollutants$\mathrm{SO}_{2}$, NOx, RSPM-Respirable Suspended Particulate Matter, NRSPM-Non Respirable Suspended Particulate Matter.)

\section{INTRODUCTION}

Environmental pollution is most frightening issue world facing today. Over population, insufficient public facilities [1], urbanization [2], automobile emissions [3] and industrialization [4-6] affecting overall quality of environment. These factors are weakening human health, assets and climate [7-10]. Sulphur dioxide, nitrogen oxides and particulate matter are crucial pollutants identified by environment protection agency. Factors like pollution sources-local and distant, meteorological and topographical conditions, variations-spatial and temporal [11-14] decides the amount of pollutants within a particular area. Accurate knowledge of concentration and variation of air pollutants and field data helps in management of environment problems [15, 16]. For controlling these problems EPA initiated Air Quality Index (AQI) which mathematically links concentration of various pollutants and gives a single value indicating quality of air at a place based on rating scale [17-20]. Bikaner city, India found higher particulate matter during winters than monsoon [21]. $\mathrm{PM}_{10}$ was a critical pollutant in Vapi city in India [22]. Increase in

\author{
MazaharFarooqui ${ }^{2}$ \\ ${ }^{2}$ Department of Chemistry, Dr. Rafiq Zakaria College for \\ Women, Navkhanda, Aurangabad-431001, (MS), India
}

PM10 and PM2.5 are responsible for higher pollution in Delhi in 2013 [23]. 72 AAQM stations compiled data showed moderate to below quality of air for 2013-14 [24]. In continuation of earlier work [25-29] the present paper explores the comparative study of ambient air quality at IMA hall (residential site) and Krishidhan Seeds (industrial) sites of Jalna city for the years 2016 and 2017 using Air Quality Index (AQI).

\section{MATERIALS AND METHODS}

\section{A. Study area}

Jalna district is in middle part of Maharashtra state and on northern direction of Marathwada region, India with north latitudes $19^{\circ} 1^{1}$ to $23^{\circ} 3^{1}$ and $75^{\circ} 4^{1}$ to $76^{\circ} 4^{1}$ east longitudes, having an area of $7612 \mathrm{~km}^{2}$. District has subtropical climate with bulk rainfall of around 450$700 \mathrm{~mm}$ from southwest monsoon between June to September. During drought rainfall reduces to 400 to 450 $\mathrm{mm}$. After monsoon in winter minimum temperature falls to $9^{\circ}-10^{\circ} \mathrm{C}$ and maximum goes to $30-35^{\circ} \mathrm{C}$. In summer maximum day temperature reaches to $42-45^{\circ} \mathrm{C}[30,31]$.

Industrially Jalna is famous for Seeds, Steel along with other areas Engineering, Plastic and Agriculture. City is having six industrial areas under MIDC having industries of pulses, oil mills, refineries, steel re-rolling, plastics, tiles, cement pipes, fertilizers, insecticides, pesticides and the cooperative sugar factories. These industries along with automobiles and construction are the key air polluting factors in the city $[32,33]$.

\section{B. Sampling and analysis of particulate pollutant (RSPM and NRSPM):}

Twice a week during January to December 2016 and 2017 RSPM, NRSPM, $\mathrm{SO}_{2}$ and NOx samples were collected from both sites using High volume air sampler (model RDS APM 460NL) with attachment APM 411TE (Enviro-tech make) can work for 24 hours. For RSPM and NRSPM air flow rate maintained at $1.1-1.2 \mathrm{~m}^{3} / \mathrm{min}$ for 8 hours. The cyclone separator gathers bigger particles NRSPM $>10 \mu \mathrm{m}$ size on previously weighed dust collector in first stage, RSPM (size $<10 \mu \mathrm{m})$ were collected on Whatmann GF/A glass microfiber filter. Using CPCB 2011 [34] gravimetrically the concentration of RSPM and NRSPM were found. 


\section{Gaseous pollutants $\left(\mathrm{SO}_{2}\right.$ and $\left.\mathrm{NOx}\right)$}

$\mathrm{SO}_{2}$ air samples were absorbed in absorbent solution of potassium tetrachloromercurate (TCM), complex formed dichlorosulphitomercurate was made to react with para rosaniline and methyl sulphonic acid. Spectrophotometer measures absorbance at $530 \mathrm{~nm}$ of formed sulphate ions concentration in absorbent using West and Gaeke Method (IS 5182 part 2:2001); CPCB 2001 [35].

Nitrogen dioxide from air bubbled through a solution of sodium hydroxide and sodium arsenite. Nitrile ion produced was treated with phosphoric acid, sulphanilamide and N-(1-naphthyl)-ethylenediamine dihydrochloride (NEDA) and measuring the absorbance of the highly coloured azo-dye at 540nm [36, 37].

\section{Air Quality Index (AQI)}

AQI is a single number showing real concentration of criteria pollutants compared to its standard permissible values [38, 39]. AQI guides in analyzing and representing uniform air quality grade.

AQI equation is

$$
A Q I=\left(\frac{100}{n}\right) \sum_{k=1}^{n}\left(\frac{A P C_{k}}{S P C_{k}}\right)
$$

Where, AQI= Air Quality Index $\mathrm{n}=$ number of criteria pollutants $\mathrm{APC}=$ Actual Pollutant Concentration SPC $=$ Standard Pollutant Concentration (CPCB 2011)

\begin{tabular}{|c|c|c|c|c|}
\hline \multirow[t]{2}{*}{ Sr. No. } & \multirow[t]{2}{*}{ Pollutant } & \multirow{2}{*}{$\begin{array}{c}\text { Time weighted } \\
\text { Average }\end{array}$} & \multicolumn{2}{|c|}{ Air Quality Standard concentration in Ambient air } \\
\hline & & & $\begin{array}{l}\text { Industrial, residential, rural and } \\
\text { other area }\end{array}$ & $\begin{array}{l}\text { Ecologically sensitive area } \\
\text { (notified by central Govt.) }\end{array}$ \\
\hline 1 & $\mathrm{SO}_{2} \mu \mathrm{gm} / \mathrm{m}^{3}$ & $\begin{array}{l}\text { Annual } \\
24 \text { hours }\end{array}$ & $\begin{array}{r}50 \\
80 \\
\end{array}$ & $\begin{array}{r}20 \\
80 \\
\end{array}$ \\
\hline 2 & $\mathrm{NO}_{2} \mu \mathrm{gm} / \mathrm{m}^{3}$ & $\begin{array}{l}\text { Annual } \\
24 \text { hours }\end{array}$ & $\begin{array}{l}40 \\
80 \\
\end{array}$ & $\begin{array}{l}30 \\
80\end{array}$ \\
\hline 3 & $\mathrm{PM}_{10} \mu \mathrm{gm} / \mathrm{m}^{3}$ & $\begin{array}{c}\text { Annual } \\
24 \text { hours }\end{array}$ & $\begin{array}{c}60 \\
100 \\
\end{array}$ & $\begin{array}{c}60 \\
100 \\
\end{array}$ \\
\hline 4 & $\mathrm{PM}_{2.5} \mu \mathrm{gm} / \mathrm{m}^{3}$ & $\begin{array}{l}\text { Annual } \\
24 \text { hours }\end{array}$ & $\begin{array}{l}40 \\
60\end{array}$ & $\begin{array}{l}40 \\
60\end{array}$ \\
\hline
\end{tabular}

Table 1:- Indian National Ambient Air quality standard

AQI rating scale of is as shown below.

\begin{tabular}{|c|c|}
\hline AQI value & AQI Category \\
\hline $0-50$ & Good \\
\hline $51-100$ & Satisfactory \\
\hline $101-200$ & Moderately polluted \\
\hline $201-300$ & Poor \\
\hline $301-400$ & Very poor \\
\hline$>401$ & Severe \\
\hline
\end{tabular}

Table 2:- Air Quality Index (AQI) Rating Scale.

\section{RESULTS AND DISCUSSION}

Monthly average concentrations of $\mathrm{SO}_{2}, \mathrm{NOx}, \mathrm{RSPM}$ and NRSPM monitored at residential and industrial sites for the year 2016 and 2017 has been presented in table.3, 4 and represented graphically in charts.1, 2 respectively. While seasonal variation in concentrations have been reported in table. 5 and represented graphically in charts-3, 4 respectively.

\begin{tabular}{|c|c|c|c|c|c|c|c|c|}
\hline \multirow{2}{*}{ Month } & \multicolumn{4}{|c|}{ For the year 2016 } & \multicolumn{4}{c|}{ For the year 2017 } \\
\cline { 2 - 9 } & $\mathbf{S O}_{2}$ & NOx & RSPM & NRSPM & $\mathbf{S O}_{2}$ & NOx & RSPM & NRSPM \\
\hline Jan & 12.63 & 6 & 128.00 & 449.00 & 12.26 & 32.06 & 121.00 & 370.00 \\
\hline Feb & 12.24 & 30.00 & 124.00 & 503.00 & 13.80 & 34.45 & 140.00 & 433.00 \\
\hline Mar & 11.58 & 27.84 & 122.00 & 489.00 & 13.27 & 31.80 & 157.00 & 441.00 \\
\hline Apr & 12.32 & 28.47 & 128.00 & 478.00 & 12.90 & 31.05 & 162.00 & 354.00 \\
\hline May & 13.35 & 31.81 & 128.00 & 411.00 & 12.25 & 31.00 & 106.00 & 342.00 \\
\hline June & 9.00 & 27.19 & 110.00 & 368.00 & 8.00 & 27.45 & 88.00 & 270.00 \\
\hline July & 11.96 & 29.43 & 98.00 & 305.00 & 7.13 & 26.29 & 91.00 & 283.00 \\
\hline Aug & 11.80 & 27.20 & 97.56 & 366.00 & 8.14 & 27.52 & 96.00 & 289.00 \\
\hline Sept & 11.38 & 28.17 & 84.00 & 237.00 & 9.56 & 28.31 & 77.00 & 180.00 \\
\hline Oct & 4.27 & 30.81 & 118.00 & 478.00 & 11.17 & 29.58 & 134.00 & 391.00 \\
\hline Nov & 5.16 & 30.69 & 208.00 & 720.00 & 14.00 & 31.26 & 143.00 & 424.00 \\
\hline Dec & 13.84 & 35.72 & 188.00 & 749.00 & 14.43 & 29.10 & 129.00 & 398.00 \\
\hline Avg. & $\mathbf{1 0 . 7 9}$ & $\mathbf{2 9 . 7 2}$ & $\mathbf{1 2 7 . 7 9}$ & $\mathbf{4 6 2 . 7 5}$ & $\mathbf{1 1 . 4 0}$ & $\mathbf{2 9 . 9 8}$ & $\mathbf{1 2 0 . 3 0}$ & $\mathbf{3 4 7 . 9 0}$ \\
\hline
\end{tabular}

Table 3:- Monthly average concentration of $\mathrm{SO}_{2}, \mathrm{NOx}, \mathrm{RSPM}$ and SPM $\left(\mu \mathrm{gm} / \mathrm{m}^{3}\right)$ at residential site for the year 2016 and 2017. 


\begin{tabular}{|c|c|c|c|c|c|c|c|c|}
\hline \multirow{2}{*}{ Month } & \multicolumn{4}{|c|}{ For the year 2016 } & \multicolumn{4}{c|}{ For the year 2017 } \\
\cline { 2 - 9 } & $\mathbf{S O}_{2}$ & NOx & RSPM & NRSPM & SO $_{2}$ & NOx & RSPM & NRSPM \\
\hline Jan & 11.71 & 31.62 & 93.00 & 227.00 & 13.77 & 34.31 & 206.00 & 781.00 \\
\hline Feb & 11.93 & 29.41 & 94.00 & 232.00 & 12.94 & 32.60 & 257.00 & 507.00 \\
\hline Mar & 13.52 & 13.52 & 95.00 & 241.00 & 12.25 & 31.80 & 132.00 & 313.00 \\
\hline Apr & 13.44 & 32.81 & 92.00 & 374.00 & 12.90 & 31.05 & 162.00 & 354.00 \\
\hline May & 11.49 & 31.24 & 89.00 & 356.00 & 12.72 & 31.20 & 130.00 & 347.00 \\
\hline June & 9.25 & 26.61 & 82.00 & 288.00 & 8.09 & 27.45 & 101.00 & 193.00 \\
\hline July & 12.63 & 27.48 & 89.00 & 200.00 & 10.96 & 28.08 & 95.00 & 264.00 \\
\hline Aug & 12.06 & 28.62 & 83.00 & 275.00 & 9.26 & 26.12 & 90.00 & 196.00 \\
\hline Sept & 11.70 & 27.66 & 78.00 & 258.00 & 10.57 & 28.52 & 72.00 & 220.00 \\
\hline Oct & 12.91 & 30.81 & 91.00 & 289.00 & 11.80 & 31.00 & 89.00 & 238.00 \\
\hline Nov & 8.37 & 37.24 & 87.00 & 164.00 & 13.20 & 33.00 & 91.00 & 201.00 \\
\hline Dec & 13.70 & 35.53 & 89.00 & 200.00 & 11.50 & 31.24 & 91.00 & 209.00 \\
\hline Avg. & $\mathbf{1 1 . 8 9}$ & $\mathbf{2 9 . 3 7}$ & $\mathbf{8 8 . 5 0}$ & $\mathbf{2 5 8 . 6 6}$ & $\mathbf{1 1 . 7 0}$ & $\mathbf{3 0 . 5 3}$ & $\mathbf{1 2 6 . 3 0}$ & $\mathbf{3 1 8 . 6 0}$ \\
\hline
\end{tabular}

Table 4:- Monthly average concentration of $\mathrm{SO}_{2}, \mathrm{NOx}, \mathrm{RSPM}$ and SPM $\left(\mu \mathrm{gm} / \mathrm{m}^{3}\right)$ at industrial site for the year 2016 and 2017.

\section{A. Sulphur dioxide $\left(\mathrm{SO}_{2}\right)$}

At residential site: The monthly average concentration was varied between $4.27-13.84 \mu \mathrm{g} / \mathrm{m}^{3}$ in 2016 while it varied between $7.13-14.43 \mu \mathrm{g} / \mathrm{m}^{3}$ in the year 2017 respectively. The highest concentration of $\mathrm{SO}_{2} 13.84 \mu \mathrm{g} / \mathrm{m}^{3}$ was recorded in December of 2016 while it was recorded highest $14.43 \mu \mathrm{g} / \mathrm{m}^{3}$ again in December of the year 2017. The lowest average concentration of $\mathrm{SO}_{2} 4.27 \mu \mathrm{g} / \mathrm{m}^{3}$ was observed in month October month of the year 2016, while lowest average concentration $\mathrm{SO}_{2} 7.13 \mu \mathrm{g} / \mathrm{m}^{3}$ was recorded in July of 2017. The yearly average concentration of $\mathrm{SO}_{2}$ was $10.79 \mu \mathrm{g} / \mathrm{m}^{3}$ for the year 2016 was found to be lower compared to $11.40 \mu \mathrm{g} / \mathrm{m}^{3}$ for the year 2017 , both are below the national ambient air quality standards (NAAQS) specified by the central pollution control board (CPCB 2009). The highest of average seasonal concentration of $\mathrm{SO}_{2} 12.37 \mu \mathrm{g} / \mathrm{m}^{3}$ was observed in summer for the year 2016, while for the year 2017 it was found to be $13.05 \mu \mathrm{g} / \mathrm{m}^{3}$ again in summer. The least seasonal average $\mathrm{SO}_{2}$ concentration was found to be $8.98 \mu \mathrm{g} / \mathrm{m}^{3}$ in winter for the year 2016, while for 2017 it was $8.20 \mu \mathrm{g} / \mathrm{m}^{3}$ in monsoon.

At industrial site: The monthly average concentration was varied between $8.37-13.70 \mu \mathrm{g} / \mathrm{m}^{3}$ in 2016 while it varied between $8.09-13.77 \mu \mathrm{g} / \mathrm{m}^{3}$ in the year 2017 respectively which is nearly a similar form of variation. The highest average concentration of $\mathrm{SO}_{2} 13.70 \mu \mathrm{g} / \mathrm{m}^{3}$ was recorded in December of 2016 while it was recorded highest $13.77 \mu \mathrm{g} / \mathrm{m}^{3}$ in January month of the year 2017. The highest values for both these years are found to be very close. The lowest average concentration of $\mathrm{SO}_{2} \quad 8.37 \mu \mathrm{g} / \mathrm{m}^{3}$ was observed in month November month of 2016, while it was found to be $8.09 \mu \mathrm{g} / \mathrm{m}^{3}$ in June for the year 2017 . The lowest values are once again very close. The annual average $\mathrm{SO}_{2}$ concentration were $11.89 \mu \mathrm{g} / \mathrm{m}^{3}$ for the year 2016 and $11.70 \mu \mathrm{g} / \mathrm{m}^{3}$ for the year 2017, which were below the national ambient air quality standards (NAAQS) specified by the central pollution control board (CPCB 2009) [40]. The highest of average seasonal concentration of $\mathrm{SO}_{2}$ $12.60 \mu \mathrm{g} / \mathrm{m}^{3}$ was observed in summer for the year 2016 , while for the year 2017 it was found to be $12.70 \mu \mathrm{g} / \mathrm{m}^{3}$ again in summer. The least seasonal average $\mathrm{SO}_{2}$ concentration was found to be $11.41 \mu \mathrm{g} / \mathrm{m}^{3}$ in monsoon for the year 2016 , while for 2017 it was $9.72 \mu \mathrm{g} / \mathrm{m}^{3}$ in monsoon.

\section{B. Oxides of Nitrogen (NOx)}

At residential site: The average monthly concentrations of oxides of nitrogen (NOx) were varied between $27.19-35.72 \mu \mathrm{g} / \mathrm{m}^{3}$ in 2016 , while it varied between $26.29-34.45 \mu \mathrm{g} / \mathrm{m}^{3}$ in 2017 . The highest monthly average concentration of NOx $35.72 \mu \mathrm{g} / \mathrm{m}^{3}$ was recorded in December of 2016 , while it was recorded $34.45 \mu \mathrm{g} / \mathrm{m}^{3}$ in February month of 2017. The lowest monthly average concentration of NOx $27.19 \mu \mathrm{g} / \mathrm{m}^{3}$ was observed in June month of 2016, while it was recorded $26.29 \mu \mathrm{g} / \mathrm{m}^{3}$ in July month of 2017. The yearly average concentration of NOx was found to be $29.72 \mu \mathrm{g} / \mathrm{m}^{3}$ in the year 2016 compared to $29.98 \mu \mathrm{g} / \mathrm{m}^{3}$ in the year 2017. Thus yearly average concentration of $\mathrm{NOx}$ was found only slightly lower in 2016 than in 2017. The highest average seasonal concentration of NOx was observed $31.65 \mu \mathrm{g} / \mathrm{m}^{3}$ in winter of 2016 while it was found $37.42 \mu \mathrm{g} / \mathrm{m}^{3}$ in summer of 2017 . The least average seasonal concentration of NOx was observed $28 \mu \mathrm{g} / \mathrm{m}^{3}$ in monsoon of 2016, similarly for 2017 was found $27.39 \mu \mathrm{g} / \mathrm{m}^{3}$ in monsoon again.

At industrial site: The average monthly concentrations of oxides of nitrogen (NOx) were varied between $13.52-37.24 \mu \mathrm{g} / \mathrm{m}^{3}$ in 2016 , while it varied between $26.12-34.31 \mu \mathrm{g} / \mathrm{m}^{3}$ in 2017 . The highest monthly average concentration of $\mathrm{NOx} 37.24 \mu \mathrm{g} / \mathrm{m}^{3}$ was recorded in November of 2016 , while it was recorded $34.31 \mu \mathrm{g} / \mathrm{m}^{3}$ in January month of 2017. The lowest monthly average concentration of NOx $13.52 \mu \mathrm{g} / \mathrm{m}^{3}$ was observed in March month of 2016 , while it was recorded $26.12 \mu \mathrm{g} / \mathrm{m}^{3}$ in August month of 2017. The yearly average concentration of NOx was found to be $29.37 \mu \mathrm{g} / \mathrm{m}^{3}$ in the year 2016 compared to $30.54 \mu \mathrm{g} / \mathrm{m}^{3}$ in the year 2017 . Thus yearly average concentration of NOx was found only slightly lower in 2016 than in 2017. The highest average seasonal concentration of NOx was observed $33.80 \mu \mathrm{g} / \mathrm{m}^{3}$ in winter of 2016 while it was found $32.38 \mu \mathrm{g} / \mathrm{m}^{3}$ again in winter of 2017. The least average seasonal concentration of NOx was 
observed $26.75 \mu \mathrm{g} / \mathrm{m}^{3}$ in summer for 2016; similarly for 2017 it was found $27.54 \mu \mathrm{g} / \mathrm{m}^{3}$ in monsoon. NOx values obtained were well below the NAAQS (CPCB 2009) for both the years.

Sulphur dioxide and oxides of nitrogen are the key pollutant contributing to ambient air which is given out by fossil fuel burning, automobiles and industries [41, 42]. The seasonal concentration pattern of air pollutants is driven by emission characteristics of the dominant sources and meteorological conditions [13]. Researchers [43-45] reported similar observations.

\begin{tabular}{|c|c|c|c|c|c|}
\hline \multirow[t]{2}{*}{ Season } & \multirow[t]{2}{*}{ Pollutant } & \multicolumn{2}{|c|}{ Residential } & \multicolumn{2}{|c|}{ Industrial } \\
\hline & & 2016 & 2017 & 2016 & 2017 \\
\hline \multirow[t]{5}{*}{ Summer } & $\mathrm{SO}_{2}$ & 12.37 & 13.05 & 12.60 & 12.70 \\
\hline & NOx & 29.53 & 37.42 & 26.75 & 31.66 \\
\hline & RSPM & 125.50 & 141.25 & 92.50 & 170.25 \\
\hline & SPM & 470.25 & 392.50 & 300.75 & 380.25 \\
\hline & $\mathrm{AQI}$ & 125.50 & 141.25 & 92.50 & 170.25 \\
\hline \multirow[t]{5}{*}{ Monsoon } & $\mathrm{SO}_{2}$ & 11.04 & 8.20 & 11.41 & 9.72 \\
\hline & NOx & 28.00 & 27.39 & 27.59 & 27.54 \\
\hline & RSPM & 97.39 & 88.00 & 83.00 & 89.50 \\
\hline & SPM & 319.00 & 225.50 & 255.25 & 250.00 \\
\hline & AQI & 97.39 & 88.00 & 83.00 & 89.50 \\
\hline \multirow[t]{5}{*}{ Winter } & $\mathrm{SO}_{2}$ & 8.98 & 12.96 & 11.67 & 12.56 \\
\hline & NOx & 31.65 & 30.50 & 33.80 & 32.38 \\
\hline & RSPM & 160.50 & 131.75 & 90.00 & 119.25 \\
\hline & SPM & 599.00 & 395.75 & 220.00 & 357.25 \\
\hline & AQI & 160.50 & 131.75 & 90.00 & 119.25 \\
\hline
\end{tabular}

Table 5:- Seasonal average concentration of pollutants $\left(\mu \mathrm{gm} / \mathrm{m}^{3}\right)$ at residential and industrial sites for the year 2016 and 2017.

C. Particulate pollutants

$>$ Respirable suspended particulate matter RSPM $(\leq$ $\left.P M_{10}\right)$

At residential site: The annual mean concentration of RSPM was observed $127.79 \mu \mathrm{g} / \mathrm{m}^{3}$ in the year 2016 while $120.30 \mu \mathrm{g} / \mathrm{m}^{3}$ in the year 2017 which are ahead of the maximum permissible limit of NAAQS (Table.1). November recorded highest monthly average RSPM concentration $208 \mu \mathrm{g} / \mathrm{m}^{3}$ in the year 2016, while in the 2017 it was found highest $157 \mu \mathrm{g} / \mathrm{m}^{3}$ in March. The lowest RSPM was recorded $84 \mu \mathrm{g} / \mathrm{m}^{3}$ in September 2016, while for the year 2017 recorded $77 \mu \mathrm{g} / \mathrm{m}^{3}$ again in September. Seasonally winter recorded highest levels of RSPM $160.50 \mu \mathrm{g} / \mathrm{m}^{3}$ in 2016 , while $141.25 \mu \mathrm{g} / \mathrm{m}^{3}$ was recorded highest in summer of 2017. Monthly average RSPM concentration ranged between $84-208 \mu \mathrm{g} / \mathrm{m}^{3}$ in 2016 while it ranged between $88-157 \mu \mathrm{g} / \mathrm{m}^{3}$ in 2017 .

At industrial site: The annual mean concentration of RSPM was observed $88.50 \mu \mathrm{g} / \mathrm{m}^{3}$ in the year 2016 which is within the permissible limit of NAAQS. But in the year 2017 the annual mean concentration of RSPM was found to be $126.30 \mu \mathrm{g} / \mathrm{m}^{3}$ which is above the permissible limits of NAAQS (Table.1). March 2016 recorded highest monthly average RSPM concentration $95 \mu \mathrm{g} / \mathrm{m}^{3}$ while February 2017 recorded $257 \mu \mathrm{g} / \mathrm{m}^{3}$ as highest concentration of RSPM. The lowest RSPM was recorded $78 \mu \mathrm{g} / \mathrm{m}^{3}$ in September 2016, while for the year 2017 recorded $72 \mu \mathrm{g} / \mathrm{m}^{3}$ again in September. Lowest concentration of RSPM both at residential and industrial sites was recorded in September for both the years which is the rainy month. Seasonally summer recorded highest levels of RSPM $92.50 \mu \mathrm{g} / \mathrm{m}^{3}$ in 2016, while $170.25 \mu \mathrm{g} / \mathrm{m}^{3}$ was recorded highest again in summer of 2017. Monthly average RSPM concentration ranged between $78-95 \mu \mathrm{g} / \mathrm{m}^{3}$ in 2016 while it ranged between $72-257 \mu \mathrm{g} / \mathrm{m}^{3}$ in 2017 .

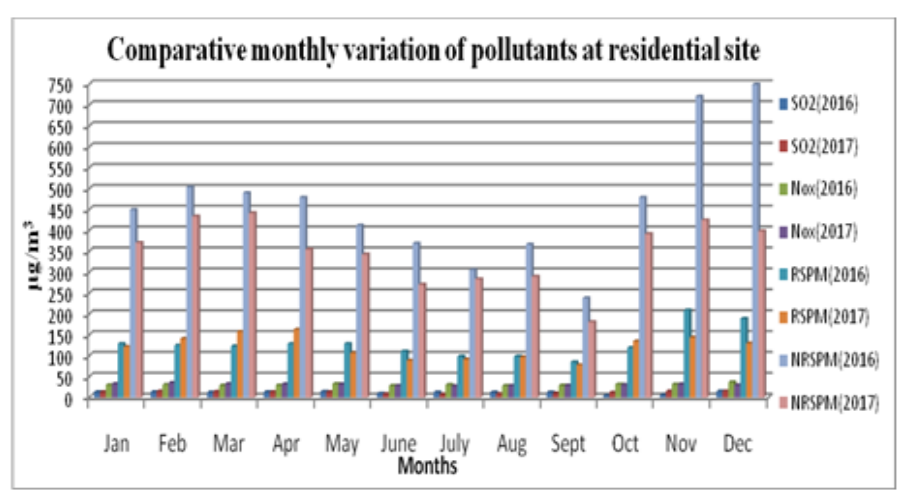

Chart 1

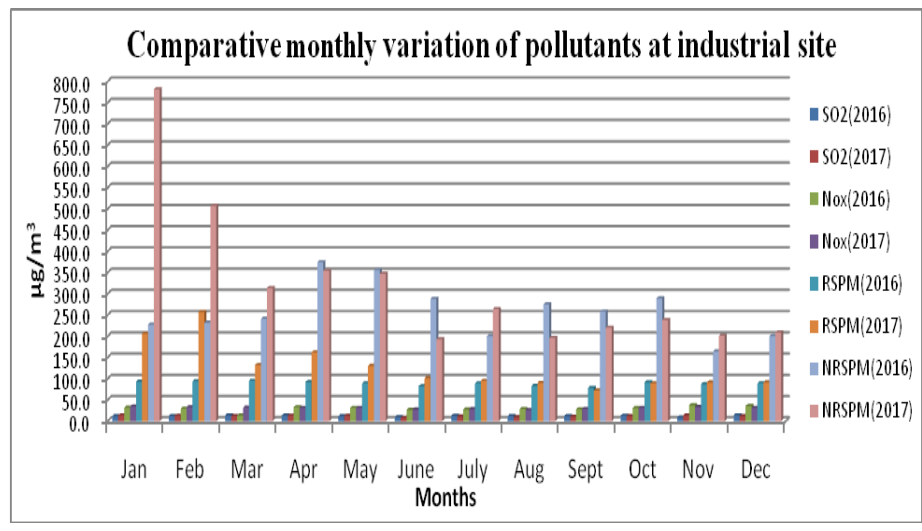

Chart 2 


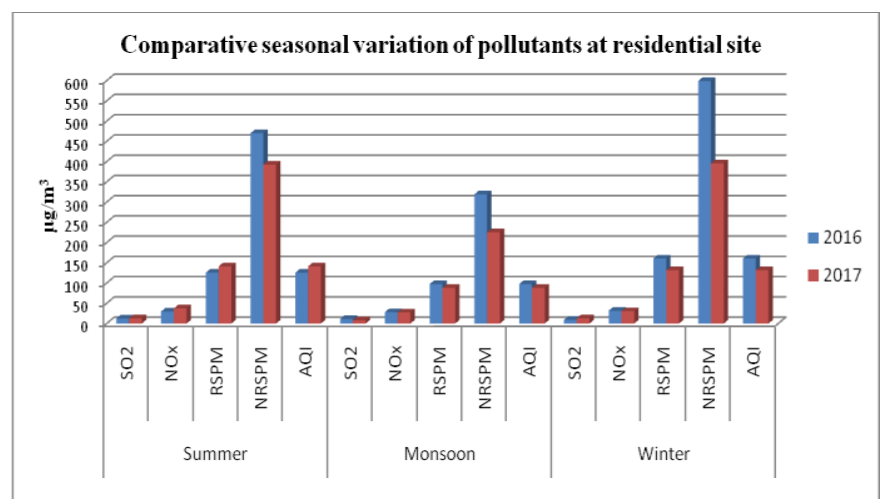

Chart 3

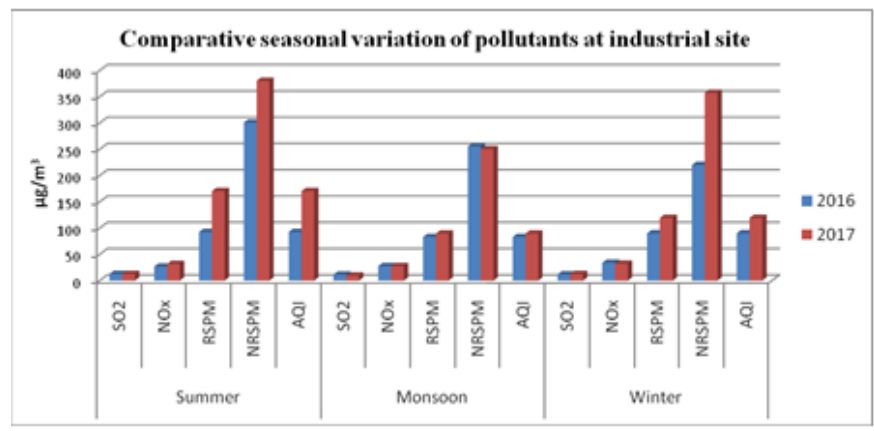

Chart 4

Non Respirable Suspended particulate matter (NRSPM) $\geq P M_{10}$ :

At residential site: The annual mean concentration of NRSPM was observed $462.75 \mu \mathrm{g} / \mathrm{m}^{3}$ in the year 2016 while $347.90 \mu \mathrm{g} / \mathrm{m}^{3}$ in the year 2017 which are ahead of the maximum permissible limit of NAAQS. December recorded highest monthly average NRSPM concentration $749 \mu \mathrm{g} / \mathrm{m}^{3}$ in the year 2016, while in the 2017 it was found highest $441 \mu \mathrm{g} / \mathrm{m}^{3}$ in March. The lowest NRSPM was recorded as $237 \mu \mathrm{g} / \mathrm{m}^{3}$ in September 2016, while for the year 2017 recorded $180 \mu \mathrm{g} / \mathrm{m}^{3}$ again in September. Seasonally winter recorded highest levels of NRSPM $599 \mu \mathrm{g} / \mathrm{m}^{3}$ in 2016 , while $395.95 \mu \mathrm{g} / \mathrm{m}^{3}$ was recorded highest in winter of 2017. Monthly average NRSPM concentration ranged between $237-749 \mu \mathrm{g} / \mathrm{m}^{3}$ in 2016 while it ranged between $180-441 \mu \mathrm{g} / \mathrm{m}^{3}$ in 2017 .

At industrial site: The annual mean concentration of NRSPM was observed $258.66 \mu \mathrm{g} / \mathrm{m}^{3}$ in the year 2016 and in the year 2017 it was found to be $318.60 \mu \mathrm{g} / \mathrm{m}^{3}$ suggesting higher values than the permissible limits of NAAQS. April 2016 recorded highest monthly average NRSPM concentration $374 \mu \mathrm{g} / \mathrm{m}^{3}$ while January 2017 recorded $781 \mu \mathrm{g} / \mathrm{m}^{3}$ as highest concentration of NRSPM. The lowest NRSPM was recorded $164 \mu \mathrm{g} / \mathrm{m}^{3}$ in November 2016, while for the year 2017 recorded $193 \mu \mathrm{g} / \mathrm{m}^{3}$ in June. Seasonally summer recorded highest levels of NRSPM $300.75 \mu \mathrm{g} / \mathrm{m}^{3}$ in 2016 , while $380.25 \mu \mathrm{g} / \mathrm{m}^{3}$ was recorded highest again in summer of 2017. Monthly average NRSPM concentration ranged between $164-374 \mu \mathrm{g} / \mathrm{m}^{3}$ in 2016 while it ranged between $193-781 \mu \mathrm{g} / \mathrm{m}^{3}$ in 2017.
Thus particulate matter concentration was found at residential and industrial site for both the years. The major contributors of particulate matter in ambient air are automobiles and industries [7, 43, 44]. The seasonal variation pattern of RSPM and NRSPM concentration can be seen from the values presented in table.5. The variation pattern is caused by the meteorological effects i.e. vertical mixing in summer and frequent inversions in winter [13, 44, 48]. The pattern for urban areas are basically similar for both summer and winter suggesting that most important emission sources are seasonally independent for urban areas and are surely traffic emissions and industries[49]. AQI values for residential site obtained are between 83 and 92.50 for the year 2016. While for the year 2017 AQI values are in between 89.50 and 170.50 due to higher particulate matter indicate moderate pollution as per rating scale (Table.2). Members of sensitive groups like older adults and children may experience health effects like heart or lung disease on prolong exposure and at greater risk [50] compared to general public which is affected to lesser extent.

\section{CONCLUSIONS}

Comparative analysis of temporal and spatial variations of $\mathrm{SO}_{2}$, NOx, RSPM and NRSPM for the year 2016 and 2017 of continuous measurements at Jalna city area- residential and industrial sites revealed that gaseous pollutants were found within the permissible limits of NAAQS, while the particulate pollutants violated the norms for both the years and at both the sites. The annual AQI at residential site for 2016 was 128 which is higher than 120 for the year 2017. Thus for both the years residential sites pollution is in moderately polluted category. For industrial site the AQI values 88 for 2016 and 120 for 2017 suggest satisfactory for 2016 and moderately polluted AQI category for 2017. For both the years particulate pollutants RSPM and NRSPM are key pollutants responsible for higher AQI values and industries, automobiles, construction work, combustion activities, agricultural activities, mining activities and deforestation are major contributors of particulate pollutants. People with heart or lung diseases, children and older adults are the most likely to be affected by particulate particles pollution exposure and must be protected from the same.

\section{ACKNOWLEDGEMENTS}

Authors are thankful to Director, Maharashtra pollution control board (MPCB), Aurangabad for providing financial, technical and scientific support for the present study. We also extend our thanks to Badrinarayan Barwale College, Jalna for providing supports like laboratory, infrastructure and co-operation. We are also thankful to Enviro-tech lab for useful co-operation, suggestion and also to those who helped directly and indirectly for this work. 


\section{REFERENCES}

[1]. Tashiro $\mathrm{Y}$ and Taniyama T, 2002, Atmos. $\mathrm{NO}_{2}$ and CO concentration in Lima, Peru, Env. Int., 28: $227-$ 333.

[2]. Atash F, 2007, the determination of urban environments in developing countries: Mitigating the air pollution crises in Tehran, Iran cities, 24 (6): 399 409.

[3]. Baladauf $\mathrm{R} \mathrm{W}$, Watkinns $\mathrm{N}$, Heist D, Bailey C, Rowley P and Shores R, 2009, Near air quality monitoring factors affecting network design and interpretation of data, Air Quality Atmos. and Health, 2: 1-9.

[4]. Harison R M and Yin J, 2000, Particulate matter in the Atmos.: which particle properties are important for its effects on health? The Sci. of the Total Env. 249: 85101.

[5]. Kim K H, Lee J H, and Jang M S, 2002, Metals in Airborne particulate matter from first and second industrial complex area of Taejon City, Korea, Env. Poll. 118, 41-51.

[6]. Sharek M, Cupre P, Bartos T, Kohutek J, Klanova J and Holoubek I, 2007, A combined approach to the evaluation of organic air poll. A case study of urban air in Sarajevo and Tuzla (Bosnia and Harzegovina), Sci. of the total Env. 384 (13): 182-193.

[7]. Hrdlickova Z, Michalek J, Kolar M and Vesley V, 2008, Identification of factors affecting air poll. by dust aerosol $\mathrm{PM}_{10}$ in Brno city, Czeck Republic, Atmos. Env., 42(37), 8661-8673.

[8]. Gupta A K, Patil R S and Gupta S K, 2003, A long term study of oxides of nitrogen, Env. Sci. and Health, 38: 2877-2894.

[9]. Celis J E, Morales J R, Zaror C A and Inzunza J C, 2004, A study of particulate matter $\mathrm{PM}_{10}$ composition in the atmosphere of Chile, Atmos. 54(5): 541-550.

[10]. Zhang M, Song Y and Cai X, 2007, A health based assessment of particulate air poll. in urban areas of Beijing in 2000-2004, Sci. of the Total Env., 378(13) 3: 100-108.

[11]. Franchini M and Mannucci P M, 2007, Short term effects of air pollution on cardiovascular disease outcomes and mechanisms, J. of Thrombosis and Haemostasis, 5(11): 2169-2174.

[12]. Allen R W, Davies H, Cohen M A, Mallach G, Kaufman J D and Adar S D, 2009, The spatial relationship between traffic generated air poll. and noise in 2 US cities, Env. Res., 109(3): 334-342.

[13]. Gomiscek B, Stopper S, Preining O and Hauck H, 2004, Spatial and temporal variations in $\mathrm{PM}_{1}, \mathrm{PM}_{2.5}$, $\mathrm{PM}_{10}$ and particle number concentration during AUPHEP project, Atmos. Env., 38: 3917-3934.

[14]. Rao B P S, Mhaisalkar V M, Kumar A, Shrivastava A, and Devotta S, 2009, Seasonal variations of ambient levels of Sulphur dioxide in and around a typical Indian Petroleum Refinery, Int. J. of Earth Sci. and Eng., 2(3): 231-237.

[15]. Suess M J, 1979, An Env. approach to air quality monitoring, Atmos. Env., 13:211-221.
[16]. Titta P, Raunemma T, Tissari J, Vli-Tuomi T. Leskinen A, Kukkonen J, Harkonen J and Karppinen A, 2002, Measurements and modeling of $\mathrm{PM}_{2.5}$ concentrations near a major road in Kuopio, Finland, Atmos. Env., 36:4057-4068.

[17]. Ott W R, Jr. Hunt W F, 1976, A quantitative evaluation of the pollutant standard index, J. of Air Poll. Cont. Assoc., 26:1950-1954.

[18]. Ott W R and Thom G C, 1976, A critical review of air pollution index systems in the United States and Canada, J. of Air Poll. Cont. Assoc., 26:460-470.

[19]. USEPA, 2014, United States Env. Prot. Agency.

[20]. Ontario, 2013, Review of the Ontario air quality index and air quality health index system. Air resonance Branch, Ontario ministry of the Env., Toranto, Ontario, Canada.

[21]. Charan P D, Sahel H, 2014, Study of respirable dust in Ambient Air of Bikaner city and its impact on human health, Appl. J. of Hygiene, 3: 11-14.

[22]. Sarella G, Khanbete A K, 2015, Ambient Air Quality, Analysis using Air Quality Index. A case study of Vapi, India IJIRST 1: 68-71.

[23]. Tanuja Toppo, Madhu Thakur, Prerita Pradhan, Diksha Mishra, Comparative analysis of air pollution of Delhi and Raipur city, IJARIIT, Vol.4(3),2018,p1210-1213.

[24]. Air Quality Status of Maharashtra 2013-2014, Compilation of Air Quality data recorded by MPCB, 2014.

[25]. Aher S B, Dobhal B S and Awasthi R S, September 2014, Spatial and Temporal Variations of $\mathrm{SO}_{2}, \mathrm{NOx}$, $\mathrm{PM}_{10}$ and TSPM Concentration in Ambient Air of Jalna City, India, Int. J. of Agric., Env. \& Biotech., 7(3); 571-579.

[26]. Aher S B, Dobhal B S and Awasthi R S, 2014, Assessment of Ambient Air Quality of Jalna City, India using Air Quality Index, Indian J. of Env. Sci., 18(2): 65-72.

[27]. Dobhal B S, Jadhav Shivaji, Sangvikar Meghmala and Mazahar Farooqui, 2016, Study of Ambient Air Quality of Jalna City (MS), India, Ultra Chem., Vol. 12(2): 29-34.

[28]. B S Dobhal, R P Shimpi and Mazahar Farooqui, 2020, Ambient Air Quality Assessment of Jalna City (MS), India, Indian J. Sci. Res. 10(2): 45-53.

[29]. Bhagwansing S Dobhal, Ravindra P Shimpi, Mazahar Farooqui, December 2019, Evaluation of Ambient Air Quality of Jalna City(MS), India, International Journal of Research and Review, Vol.6; Issue:12;341351.

[30]. Rajajoseph D, Mathan Y and Rajivgandhi V. 2014. Efficient and Environment friendly NOx emission reduction design of Aero Engine gas turbine Combustor, IJEP, 34(8), 645-652.

[31]. Erika VonSchueidemesser, Paul S Monks, James D Allens, Lori Bruhwiler, Piers Forster, David Flower, Alex Lauer, William T Morgan, Pauli Passonen, MattiaRighi, Katerinasindelarova and Mark A Sutton. 2015. Chemistry and linkage between air quality and climate change, Chemical Reviews, 115, 3856-3897. 
[32]. Harison R M and Yin J. 2000. Particulate matter in atmosphere; which particle properties are important for its effects on health, The Science of the total Environment, 249, 85-101.

[33]. UNCSD. 2001. Protection of the atmosphere- Report to the secretary General, E/CN.17/2001/2, commission for sustainable Development, New York, USA.

[34]. CPCB (Central Pollution Control Board) 2011. Guidelines for the measurements of Ambient Air Pollution in New Delhi, India (1):55.

[35]. IS 5182.2, 2001. Methods for measurement of Air pollution part-2, Sulphur Dioxide (CHD 32: Environmental Protection and Waste measurement)

[36]. Jacob M B and Hochheiser S. 1958. Continuous Sampling and ultra micro determinations of nitrogen dioxide in air, Analytical Chemistry, 30:426.

[37]. IS 5182-2, 2001. Methods for measurement of Air pollution, Part 6: oxides of nitrogen (CHD 32: Environmental protection and waste management).

[38]. Bortnick S M, Coutant B W and Eberly S I. 2002. Using continuous $\mathrm{PM}_{2.5}$ monitoring data reports on Air Quality Index, Journal of the Air and waste management Association, 52: 104-112.

[39]. Murena F. 2004. Measuring air quality over large urban areas; Development and application of an air pollution Index at the urban areas of Neples, Atmospheric Environment, 38: 6195-6202.

[40]. CPCB (Central Pollution Control Board) Indian National Ambient Air Quality Standards, New Delhi.

[41]. Muschate N S and Chougale A M, 2011, Study of ambient concentration of air quality parameters $\left(\mathrm{PM}_{10}\right.$, $\mathrm{SPM}, \mathrm{SO}_{2}$ and $\mathrm{NOx}$ ) in different months, European $J$. of Experimental Biol., 1(1), 90-96.

[42]. Md. Asif Ekbal, Hrishabh Gupta, Assessment of ambient air quality index of coal city Dhanbad for public health information, vol.2, Jan-mar 2015, p 5053

[43]. Bhanarkar A D, Gajphate D. G and Hasan M Z. 2002. Air pollution concentration in Haryana sub-region, India, Bulletin of Environmental Contamination and Toxicology, 69: 690-695.

[44]. Kaushik C P, Ravindra K, Yadav K, Mehta S and HaritashA K. 2006. Assessment of ambient Air Quality in urban centers of Haryana(India) in relation of different anthropogenic activities and health risks, Environmental Monitoring and Assessment, 122: $27-$ 40.

[45]. Chauhan A, Pausar M, Kumar R and Joshi P C. 2010. Ambient Air Quality studies in Uttarakhand (India): a case study of Haridwar and Deharudan using air quality index, Journal of American Science, 6(9): 565574.

[46]. Watkins L H. 1991. Air Pollution from Road Vehicles, Transport and Road Research Laboratory, London, UK.

[47]. Nylund N O and Lawson A. 2000. Exhaust emissions from Natural gas vehicles Helsinki, International Association of Natural Gas Vehicles VTT Energy.
[48]. Gehrig R and Buchanann B. 2003. Characterizing Seasonal Variations and spatial distribution of Ambient $\mathrm{PM}_{10}$ and $\mathrm{PM}_{2.5}$ concentrations based on long term Swiss monitoring data, Atmospheric Environment, 37(19): 2571-2580.

[49]. Buzorius G, HameriK, Pekkanen J and Kulmala M. 1999. Spatial variation of aerosol number concentration in Helsinki city, Atmospheric Environment, 33(4): 553-565.

[50]. Ramesh Bhat Y, Manjunath N, Sanjay D, Dhanya Y, Association of Indoor air pollution with acute lower respiratory tract infections in children under 5 years of age, Pediatr.Int.Child Health, 2012;35:132-135. 